«Keruen» scientific journal

M.O.Auezov Institute of Literature and Art

ISSN 2078-8134

Volume 73, Number 4 (2021)

FTAMP 17.82.93

https://doi.org/10.53871/2078-8134.2021.4-18

\title{
Худайбергенов Н.Д.
}

М. О. Әуезов атындағы Әдебиет және өнер институты

Алматы қ., Қазақстан;

E-mail: nqudaibergen@gmail.com

ORCID: 0000-0003-2482-0524

\section{Қазіргі балалар поэзиясындағы көркемдік-аксиологиялық ізденістер}

(А.Естен шығармашылығы негізінде)

Андатпа. Мақалада қазіргі қазақ балалар әдебиетінің беталысы мен оның өзіндік ерекшеліктері сөз болады. Тәуелсіздік тұсындағы әдебиетке тән үрдістердің бірі -ұлттық құндылықтарды жаңғыртуға деген ұмтылыстың күшеюі. Әсіресе, ұлттың бірегейлігін танытатын, тарихы мен дәстүрінен сыр шертетін, өзіне тән менталды бітімін бүтіндейтін элементтер соңғы ширек ғасырда тек қазақ әдебиетінде ғана емес, отарлық саясаттың қамытынан босап шыққан постсоветтік елдер әдебиетінің бәрінде дерлік айқын көрініс тапты. Тарих сахнасынан ысырылып, біржола ұмыттыруға күш салынған көрнекті есімдер мен оқиғалар тәуелсіздік алғаннан кейінгі жылдарда өте қарқынды түрде жаңғырды. Ол процесс әлі де саябырси қойған жоқ.

Мақалада қазіргі қазақ балалар поэзиясының көрнекті өкілі А.Естеннің шығармашылық әлеміне шолу жасалып, тарихи-мәдени құндылықтарды жырлаудағы ақынның таланты мен талғамына баға беріледі. Автор балаларға арналған көркем әдеби туындылардың педагогикалық талаптарға қаншалықты сай келетініне назар аудартады. Сондай-ақ поэзияның аксиологиялық һәм поэтикалық қызметіне тоқталып, оның бала өміріндегі маңызын ашуға тырысады.

Бұл ғылыми мақала ҚР БҒМ Ғылым комитетінің 2020-2022 жылдарға арналған ғылыми жобалар бойынша іргелі және қолданбалы ғылыми зерттеулерді гранттық қаржыландыру бойынша АР05131632 «Қазіргі қазақ балалар әдебиетінің даму үрдістері» (1991-2021 жж.) жобасы аясында дайындалды.

Кілт сөздер: әдебиет, балалар әдебиеті, поэзия, педагогика, құндылықтар.

Кіріспе. Қазақстан халқының 30 пайызынан көп бөлігі жасы 17-ге толмаған балалар болып есептеледі (Оксамитный және Айдапкелов, 2017: 10-11). Салыстырмалы түрде алғанда, еліміз жастары көп мемлекеттердің қатарында тұр. Ал балалар тұтынып отырған интеллектуалдық-мәдени контенттің саны мен сапасына көңіл бөлу, оларды ғылыми тұрғыдан зерттеп-зерделеу тек белгілі бір ғылым саласы үшін ғана емес, тұтас мемлекеттің болашағы үшін де маңызды болып отыр. Оған қоса, БҰҰ-ның балалар құқығы туралы конвенциясында да баланың мәдени-интеллектуалдық тұрғыдан дамуына жағдай жасау жөнінде айтылады. Осы орайда, балаларға рухани-эстетикалық азық беретін көркем сөз өнерінің бүгінгі беталысына баға беріп, өзіндік ерекшеліктерін сараптап-саралау міндеті тұр. Өйткені, балаларға арналған әдебиет баланың бойындағы моральдық-этикалық құндылықтардың дұрыс болуына ғана емес, олардың психологиялық һәм эмоциялық бітімін бүтіндеуге, әлеуметтену процесінің жемісті жүруіне сеп болады.

Соңғы ширек ғасырда қазақ балалар әдебиеті трансформациялық сипатта дамыды. Iрі тарихи бетбұрыстар, елеулі қоғамдық-әлеуметтік өзгерістер өз кезегінде руханиятқа да әсер етпей қоймады. Қатаң цензурадан арылған тәуелсіздік тұсындағы әдебиетте жаңа 
тақырыптар мен жаңа жанрлар көріне бастады. Өзге де постсоветтік елдер әдебиетіндегі секілді, қазақ әдебиетінде де советтік идеологияға негізделген методологиядан саналы түрде бас тарту, тарихи сананы жаңғыртуға ұмтылыс, ұлттық құндылықтарды жандандыру сынды үрдістер басымдыққа ие болды. Ғасырға жуық әдеби-эстетикалық Темірқазық қызметін атқарған бұрынғы негізден ажырау процесі мен қаламгерлердің ұлттың бірегейлігін танытатын төл құндылықтарды жаңғыртуға деген құлшынысы тақырыптықидеялық тұрғыдан жаңа серпіліс туғызды.

Жоғарыда тілге тиек етілген әдеби үрдістер жалпы әдебиеттің ішінде ең әуелі балаларға арналған әдебиетте көрініс тапты. Біз оны әсіресе балалар әдебиетінің көрнекті өкілдерінің шығармашылығынан анық көреміз. Мысалы, поэзия мен проза жанрында қатар қалам тербейтін Арасанбай Естеннің шығармашылық әлеміне үңілгенде біз осыны байқадық. Өткен ғасырдың сексенінші жылдарынан бүгінгі күнге дейін жемісті еңбек етіп келе жатқан ақынның 10-ға жуық жинағы жарық көрген. Солардың дені балаларға арналған поэзиялық шығармалар болып есептеледі. Оның шығармаларында қазақтың бай тілі, ұлттың менталды болмысы һәм тарихи-мәдени келбеті баланың қиялына қанат бітіретін көркемдік-тәрбиелік мәні бар элементтер арқылы танылады. Әсіресе, соңғы ширек ғасырда жарық көрген туындыларының жөні бөлек. Бұл қазіргі балалар әдебиетінің даму заңдылықтарын дұрыс түсініп, оған шынайы баға беруге сеп болады деп ойлаймыз.

Талдау. Арасанбай Естен есімі аталғанда алдымен оның ақындық тұлғасы ойға оралады. Өйткені, балалар әдебиетінің шеңберінде қарасақ, оның прозасына қарағанда поэзиясы бір саты жоғары тұр. Қаламгердің поэзиясы өте бай. Мысалы, автор жанрлық тұрғыдан белгілі бір шекара-шеңбердің аясында қалып қоймайды. Оның поэзиясында поэмадан бастап мазақтамаға дейінгі 10-нан астам жанрлық үлгілерді кездестіреміз. Бұлардың бәрі, біріншіден, қаламгердің шығармашылық әлеуетін айқындай түсетін ерекшеліктер болса, екіншіден, оның шығармашылығының полифониялық сипатқа ие екенін көрсетеді. Сайып келгенде, осының бәрі балалардың бойына жалпы адамзаттық құндылықтарды сіңіруге, тарихтан тағылым түюге, әдептен аспауға, ел мен жерді қастерлеуге баулуға қызмет етеді.

Адам жаратылысының төрт түрлі негізі - оның физиологиялық, интеллектуалдық, рухани һәм эмоциялық қыры бар десек, А.Естеннің шығармашылығы баланың бойындағы аталмыш төрт қасиетті түгел қамтиды. Автор, негізінен, мынадай тақырыптарда қалам тербейді: тарих, өлкетану, табиғаттану, саламатты өмір салты және ой ұшқырлау. Табиғаттың таңғажайып құбылыстарын көркем де кестелі тілмен ұғындырған көркем туындылар баланың бойына экологиялық құндылықты сіңірсе, ой ұшқырлауға арналған ойнақы өлеңдер оның эмоциялық және танымдық қырларын шыңдай түседі. Саламатты өмір салтын ұстануды насихаттайтын өлеңдері бүлдіршіннің физиологиялық тұрғыдан дұрыс дамуына жол ашса, өлкетану мен тарихи тақырыптар балалардың интеллектуалдық қасиетін дамытып, рухани-патриоттық сезімдеріне қозғау салады.

Аталған тақырыптарды әлі оқырман ретінде көп тәжірибе жинай қоймаған, ақпарат қабылдау мәдениеті толық қалыптаспаған, бір нәрсеге ұзақ уақыт бойы зейін қойып отыра алмайтын және әлем туралы түсінігі енді қалыптанып келе жатқан аудитория өкілдеріне балаларға мазмұн мен форманы үйлестіре отырып ұсыну оңай шаруа емес. Қайта ол қолына қалам ұстаған шығармашылық адамынан үлкен шеберлікті, мол дайындықты, терең де жанжақты интеллект қуатын талап етеді. Осы орайда, балалар әдебиетін «ересектер әдебиетінен» бөліп жаруға болмайды деген пікірлердің жөн-жосықсыз екені көрініп қалады. Өйткені, балаларға арналған әдеби шығарманың көркемдік-поэтикалық деңгейі өз алдына, педагогикалық-психологиялық тұрғыдан да белгілі бір талаптарға сай болуы тиіс. Педагогикалық мақсат пен эстетикалық талап тоғысқанда ғана балаларға арналған туындылардың құны артпақшы. Көркемдік-эстетикалық бағасы төмен туынды құрғақ уағыз, жадағай туынды болып қалатыны секілді, баланың даму заңдылықтары ескерілмей жазылған көркем шығарманың да бәсі төмен. Себебі, баланың жасы, психологиясы, ақпаратты қабылдау ерекшелігі - бәрі-бәрі ескерілуге тиіс дүниелер. Бұл туралы халық 
жазушысы Қ.Мырза Әли былай дейді: «Бөбектер өлеңі - жыр мен сырдың, ой мен ойынның, сөз өнері мен педагогиканың барынша жымдасқан жері. Демек, бүлдіршінге бағышталған балауса жыр жас оқырманды сүйсіндіріп қана қоймауға тиіс. Сол сүйсінудің астарында сәби санасына судай сіңіп, тастай бататын тәрбиелік мән жатуға қажет» (Мырзалиев, 1984).

А.Естеннің поэзиясында Қадыр ақын айтқан талаптарға сай келетін өлеңдер аз емес. Бұл автордың балалар әлеміне мейлінше дендеп енгеніне дәлел болады. Автордың поэзиялық шығармаларында елеулі орын алатын тақырып - тарихи тақырып. Ол өлкетану және тұлғатану салаларының аясында ашылады. Автор қазақтың қазіргі қалаларына қарағанда тарихи шаһарлар туралы көбірек қалам тербейді. Жас оқырманының алдына тарихтың маржандарын төгіп салып, сол арқылы оның жай ғана бала емес, тарихта ірі империялар құрған, Шығыс пен Батыстың арасында алтын көпір болған, өзінің терең тарихы мен мәдениеті, бай дәстүрі мен кемел болмысы бар ұлттың өкілі екенін сезіндіргісі келетіндей. Жалпы, бұл біз зерттеу нысаны етіп отырған жазушының шығармашылығына ғана тән белгі емес. Бұл - қазіргі қазақ әдебиетінің ең негізгі үрдістерінің бірі. Солай болуың заңды. Себебі, академик С.Қасқабасовтың айтуынша, «бодандықта көп болып, тәуелсіздікке жеткен мемлекеттер өз өмірінің алғашқы 20-30 жылында тарихи сананы, тарихи жадты қайтаруға, өзінің ұлттық болмысын нығайтуға күш салады» (Қасқабасов, 2017). Қазіргі қазақ әдебиетінде зұлмат жылдарын - ашаршылық, репрессия, қуғын-сүргін құрбандарының қилы тағдырын арқау еткен туындылар осының айғағы болса керек. Біз сөз етіп отырған А.Естеннің шығармашылығында да аталмыш тақырыптың үлесі көп. Тіпті автордың «Тарихи тұлғалар туралы туындылар» деп аталатын жеке кітабы да бар (Естен, 2021). Одан бөлек, басқа да кітаптарында тарихи сананы жаңғыртуға қызмет ететін, оқырман санасына ұлттық құндылықтарды сіңіретін көркем шығармалары аз емес. Мысалы, «Тарихи тұлғалар туралы туындылар» деп аталатын кітабына қазақ тарихында есімдері өшпестей болып жазылған көрнекті тұлғалардың ерліктері мен айтулы оқиғалары, өмір жолы арқау болған. «Жолбарыс жүрек пайтшайым» деп аталатын әпсананы алайық. Қысқаша фабуласы мынадай: өнерді өмірінің өрнегі еткен Асылжанның жары кер маралдың жүрегіне жерік болады. Жарының жерік асын тауып беру үшін жолға шыққан Асылжан тау-тасты, орман-тоғайды аралап кетеді. Бір кезде бұлақтың басында айы-күні жетіп тұрған маралды көреді. Бірақ маралдың баласын жетім етуден қорқады. Сол сәтте шері шыға келіп, маралға ауыз салмақ болады. Асылжан шерді жебесімен атып, кер маралды құтқарып қалады. Жолбарыс осы маңдағы адамдардың да тынышын алып, бәрін қырып-жойып жатқан көрінеді. Жарына жолбарыстың жүрегін апарып береді. Құдайдан ұл сұрайды, бірақ қыз береді. Сол қыз аты әлемге мәшһүр Тұмар патпайым болған екен. Қысқаша сюжеттік желісі осындай. Әйтсе де, автор оқиғаны құр баяндап қоймай, балаларға обал мен сауапты, табиғатты аялауды, адамға ғана емес, жануарларға да жанашырлық таныту керегін поэтикалық тілмен ойнақы жеткізеді. Автор әпсананы былай аяқтайды:

Тарихқа құмар, досым, ал,

Бүгінше менде осы бар.

Қызықтырса, ар жағын

Ғаламтордан оқып ал (Естен, 2021: 7).

Шығарманың баяндау желісі соңғы жағына келгенде күрт өзгереді. Автор нарратологиялық-дискурстық мәнерді кенеттен құбылтып, енді оқырманның өзімен тікелей байланысқа түседі. Жай ғана байланысқа түсіп қоймай, оқушыға бағыт-бағдар береді. Қазіргі педагогикада мұғалімнің міндеті - оқушыға бағыт беру. Өйткені, XX ғасырдағыдай, алдыңа келіп тұрған шәкірттерге ақпарат-мәлімет беру жарамайды. Постиндустриалдыбілім қоғамында мұғалімнің қызметі - ақпаратты беруден гөрі оны талдауға, шынайы әрі толыққанды дүниелерді табуға көмектесуге, жаңа бір дүниелерді жасауға баулу. Осы өлшем тұрғысынан қарайтын болсақ, А.Естенді біз педагог-қаламгер деп айта аламыз. Расында да, қазір интернет кеңістігінде ақпарат көп. Бірақ оның бәрін оқып жатқан бала аз. Оларға түрткі керек. Түрткі жасау үшін автор баяндау жүйесін ұтымды қолданады. Жас оқырманмен байланыс жасау, өзімен тікелей тілдескендей болу - автордың 
коммуникативтік-көркемдік тәсілі сияқты. Мысалы, «Бөрібай көтерілісі» деген туындысында:

Келе ғой, әңгімеге қосыл, шырақ,

Тағы бір қойылды ғой тосын сұрақ.

Арада күйбең тірлік қол тигізбей,

Қалдың-ау жауабымды тосыңқырап (Естен, 2021: 15), - деп оқырман назарын тартып әкетеді. Автор, осылайша, баланың зейінін өзіне аударып, тарихи-ғылыми негізі бар аса маңызды мәліметті қабылдауға дайындайды әрі онысын өте қарапайым формада жеткізеді. Бөрібай батырдың бейнесі арқылы қазақ даласындағы қазақ-қалмақ соғысы туралы түсінік қалыптастырады. Қаламгер эпикалық суреттеу амалдарына жүгінбей, мейлінше қысқа да нұсқа үзіктермен тұтас бір картина жасайды. Клиптік сана үстем болып, ойдың твиттеризацияға ұшыраған кезеңінде балаларға осылай қысқа да нұсқа үзіктермен әсер етпесе, оқырман зейінін бір нәрсеге аударып отыру оңайға соқпайды. Сондықтан да, автор кішкентай оқырмандарға 2-3 секунд сайын бейнесі ауысып отыратын кино көріп отырғандай әсер сыйлауға тырысады. Расында да, солай. «Аманат» тарихи-тілашар дастанында қазақ даласында болған соғыстарды, сол соғыстарда ерлік көрсеткен батырлардың болмысын динамикалық сипатта ашып береді. Автор Бөрібай батырдың ерліктерін суреттей келе, шығарма соңында «титтей түйіндеме» деген айдармен қысқаша мәлімет келтіре кетеді. Ол жай мәлімет емес, ғылыми негізі бар мәлімет. «Бөрібай - Матай елінің ұранына айналған батыр (Мұхамеджан Тынышпаев. «Великие бедствия... («Ақтабан шұбырынды» кітабы.), мыңбасы. Қабанбай батырмен отыз жылдай үзеңгілес болған бас сардарларының бірі» (Естен, 2019: 15. Әрине, интернеттен мұндай мәліметті тауып алу қиын емес. Бірақ мынадай таныстырылымнан кейін бұл мәліметті оқыған бала оны ешқашан ұмыта қоймайды. Автор XX ғасырдың бас кезінде орыс отаршылдығына қарсы атқа қонған қапалдық қазақтардың әрекетін жырға қосады. «Қанқұйлы елге қылған қылапатын, Тізбелеп айта берсе шаш жетпейді...» (Естен, 2021: 18), - дей келе, «Бөрібайлап» шапқан жергілікті қазақтардың көшбасшысы Бөрібай екен деп ойлап, ақыраяғында оны таба алмай әуре-сарсаңға түскен билік өкілдерін күлкіге айналдырады:

Таяздау, ойы - тұтам, шекті - ақылы

Итаршы қызылдардың көп пақыры

Індетіп, қанша қуғын салғанымен

Таба алмай «Бөрібайды» кетті ақыры!.. (Естен, 2021: 21)

XVIII ғасырда қалмақтармен соғыста көзге түскен атақты батырдың есімімен жауға қарсы атойлап шапқандардың арасынан Бөрібайды іздеуі патшалық отарлаушылардың жергілікті мәдениет пен халықтың менталдық болмысынан бейхабар екендігін көрсетеді.

Тарихи тұлғалар туралы шығармалардың ішінде «Ән-Әміре» дастанының шоқтығы биік. Шығармада 1925 жылы 36 жасында Парижде өткен ЕХРО Халықаралық көрмесіне қатысып, әлемнің өнер алыптарымен сайысқа түсіп күміс медаль алған Әміре Қашаубаевтың ұлттық мұрат жолындағы күрескерлігі суреттеледі. Ол ұлт ұстазы Ахмет Байтұрсынұлының аманат-хатын ұлтарағының астына салып апарып, Эйфел мұнарасына шыққанда оңаша Мұстафа Шоқайға тапсырады. Алайда, елге келген соң сегіз жыл бойы азап көріп, аманатқа қиянат жасамай, арына адал күйде шейіт болған өнер адамының бейнесін оқырманның көз алдына әкеледі.

А.Естеннің тарихи тағылым сыйлап, ұлттық мұраны ұлықтайтын шығармалары топтастырылған «Көне кенттер күмбірі» кітабының жас өскіннің бойына патриоттық тәрбиені сіңіріп, тарихи сана қалыптастырудағы орны орасан. Автор әліпби бойынша әр әріпке бір не бірнеше тарихи атауыш сөздерді поэзия тілімен таныстырып, соңынан титтей түйіндеме жасап отырады. Поэзиялық туынды мен қысқаша түсініктеме бірін-бірі толықтырып тұр. Балалар әрі көркем шығарманы, әрі ғылыми түсініктемені оқып, белгілі бір тақырыппен танысады. Кітапты оқыған бала қазақ даласындағы қалаларды (Аспара, Баршынкент, Дешті Қыпшақ даласы, Доржыкент, Жанкент, Жент, Испиджаб, Құлан, Қарнақ, Отырар, Өзкент, Ақмешіт, Сарайшық, Сауран, Сығанақ, Тараз, Іңкәрқала, 
Орынбор, Қызылорда, Алматы, Астана қалалары), қазақ даласымен есіме етене байланысты ipi тұлғаларды (Гай Ле Стрэнд, Жамал Қарши, Мақдиси, Шыңғыс хан, Уәсифи) танып, толыққанды ақпар алады. Қазақ тарихын зерттеген ғалымдарды, қазақтың көне кентқалалары мен осы өңірге еңбегі сіңген ерлердің есімін жадына сіңірген балалардың жүрегіне рух, санасына сәуле құйылады. Өзінің тарихын таныған, сол арқылы жай жатқан халық емес, әлемнің өркениетіне өлшеусіз үлес қосқан ұлы халықтың төл перзенті екенін сезінеді. Сезінеді де ұлы мақсаттар жолына ұмтылады. Мысалы:

Тұмар еткен иманды

Ілім-білім жиғанды,

Түркістаным бүгін де

Кешегідей дидарлы (Естен, 2019: 35), - деген өлеңінің поэтикалық салмағы да, тарихи-концептуалдық ұғымдарды берудегі функциясы да үлкен. Өйткені, автор тарихи тақырыпты қызықты формамен, ойнақы сөзбен, соны түрмен жеткізеді. Бұл жағынан шығарма балаларға арналған әдебиеттің талаптарына толық сай деуге негіз бар.

А.Естен табиғаттың құбылыстарын, жан-жануарларды, қоршаған ортаның ерекшеліктерін балаларға таныстырғанда да оқ бойы озық тұр. Әсіресе, оның «Теңіз төріндегі тайталас» деп аталатын табиғи тілашар туындысының жөні бөлек. Теңіз патшасы теңізде өмір сүретін барша аң-мақұлық атаулыны жинап алып, жарыс өткізеді. Бұл, бір жағынан, қазақтың ауыз әдебиеті үлгілеріне ұқсайды. Кішкентайынан ертегі естіп өскен бала үшін бұл формат таныс. Бұл - баланы бірден баурап алу үшін де қажет әрі қызық түр. Жануарлардың жыл басы болуға таласқанын естіп өскен бала енді теңіздегі тіршілік иелерінің тайталасына куә болады. Әр жануар, әрбір аң өзінің артықшылықтарын айтып мақтанады. Мысалы, ақ аю былай дейді:

Жүзе де білем қиырға,

Жүздеген милің бұйым ба?

Тұра да білем қасқайып,

Қақаған қарлы құйынға (Естен, 2019: 36).

Жалпы, Қазақстан - әлемдегі мұхитқа ең алыс ел. Қазақ баласы теңіз тіршілігін терең танымайды. Әрине, өзен-көлдер бар. Оның маңайында тұратын балалардың жөні бөлек. Бірақ, жалпы алғанда, қазақ баласына теңіз тіршілігі таңсық. Ал автор осыны шебер пайдаланып, теңізді мекендейтін тіршілік иелерін әдемі әрі әсерлі таныстырады. Онысын өз аузына салады. Өзінің ең басты сипаттарын өз тілімен баяндап бергенде, қазақтың кәдімгі айтыс жанрына ұқсап кетеді. Осылайша, ақ аю, әтешбалық, баклан, бекіре, гага, дауылпаз, дельфин, жыланбалық, көк кит, құртпа, пингвин, сегізаяқ, теңіз жұлдызы, тасбақа, үкішабақ, шортан, інжу, теңіз астындағы минералдар - бәрі-бәрі елде жоқ сипатын айтысып, бас бәйгені алуға барын салады. Бірақ бас бәйге кімге бұйыратынын оқырманның өзі шешеді екен:

Талдап жарыс талқысын,

Қайсы жалған, қайсы шын.

Елеп, екшеп, саралап,

Таңдар едің қайсысын?!.

Келгендердің сан қырдан,

Қайсы сені таң қылған?..

Шеш те даудың түйінін,

Бәйгесін бер, балдырған! (Естен, 2019: 47]

А.Естен, осылайша, геймификациялық тәсілдерге жүгінеді. Бала мен шығарма арасында тікелей интерфейстік байланыс орнатып, оқылым процесін қызықтыра түседі. Ойын элементтері қосылғаннан кейін баланың күрделі танымдық-интеллектуалдық жұмысының өзі оңай әрі сауыққа негізделген процеске айналады. Ал бұл өз кезегінде маңызды тақырыптарды, жалпы адамзаттық құндылықтарды бала бойына сіңірудің таптырмас тәсілі дер едік. 
Бала жақсылықтан үйреніп, жамандықтан жиреніп өседі. Осыны ескере отырып балалар әдебиетінің өкілдері кейде насихатты ізгілікке тікелей шақыру арқылы емес, жамандықты келеке ету арқылы жеткізеді. Мысалы, әдептің шекара-шеңберінен асып, моральдық нормаларды бұзатын балаларды мазаққа айналдырады. Осыны оқыған бала да мазаққа қалудан қорқып, бейсаналы түрде оң өзгеріске қадам басады. Асылы, мазақтама жанрының негізгі миссиясы да осы. Ол біреудің кемшілік-қателігін тізбектеп теруді емес, қайта сол арқылы жамандықтан жирендіруге қызмет етуі тиіс. А.Естеннің мазақтамаларының тақырыптық аясы кең. Автор оны балаларды спортқа баулу үшін де, табиғатты аялау үшін де, ата-ананы сыйлап, қатарластарына зиян тигізбеуі үшін де пайдаланады. Мысалы, «Ұрыншақ» деген өлеңін алайық.

Кемшілік көп Сырымда:

Бестігі жоқ ырымға.

Қыздар десе, қырғидай

Өш келеді бұрымға (Естен, 2019: 83).

Мұны оқыған бала да Сырым секілді болудан сақтанып, әдептен аспауға тырысады. Автор кейде баланы тікелей бұйыру арқылы әдепке шақырады. Мысалы, «Әдептілік бастауы» деген өлеңінде:

Тазалықты құнтта,

Қол жууды ұмытпа.

Нанды үзбе бір қолмен,

Асты үрлеп суытпа (Естен, 2019: 87), - дейді. Бұл туындысын «Әдеп деген немене?» деген өлеңі толықтыра түседі:

Әдеп - иба, кішілік,

Әдеп - иман, кісілік.

Әдеп - ұят, арлылық

Сана жайлы түсінік (Естен, 2019: 92).

Балалар әдебиетін зерттеуші А.Әлтай: «Балалар қаламгерінің жас буын алдындағы басты парызы - күнделікті өмірде оқыту мен тәрбиенің өзекті мәселелерін шешуге септесетін, қоршаған ортаны, қоғамдық-әлеуметтік қарым-қатынастардың қыр-сырын біртіндеп танып-білуге баулитын, нәтижесінде жеке адам ретіндегі өзіндік дүниетанымын айқындауға үлес қосатын идеялық-көркемдік деңгейі жоғары шығармалар ұсыну», - дейді (Әлтай, 2009: 14). Осы тұрғыдан алып қарайтын болсақ, А.Естеннің өлеңдері «оқыту мен тәрбиенің өзекті мәселелерін шешуге септеседі», «қоршаған ортаны, қоғамдық-әлеуметтік қарым-қатынастарды танып-білуге баулиды».

Арасанбай Естен - балалар лирикасының шебері. Балаларға арналған өлеңдер бүлдіршіндердің қиялына қанат бітіріп, шығармашылық тұрғыдан ойлауына итермелейді. Осы арқылы баланың эмоциялық интеллекті дамып, ой-зердесі шыңдалады. М.Әлімбаевтың поэзия әлемін зерттеген Ә.Жәкім баланың сезімі мен көркем әдебиеттің арасындағы байланыс туралы былай дейді: «Адам сезімінсіз лирика деген ұғымды елестетудің өзі мүмкін емес. Оның болмысы, жаны - адам сезімі, көңіл күйі мен ішкі жан дүниесінің тебіренісі, соған сәйкес алынған көркем сөз кестесі мен оңтайлы пішінінің бірлігі екендігі сөзсіз. Осы аталғандар жиналып келіп, өлеңді оқырмандар мен тыңдармандарды рақатқа бөлейтін нағыз көркем туындыға айналдырады. Балалар поэзиясы болған соң, мұнда бала жаны, бала дүниетанымы, бала болмысы, бала мінезі көрінуі заңды. Шығарманы оқыған бала одан өзін, құрбыларын тануы қажет» (Жәкім, 2008: 70). Жоғарыда мысалға келтірілген үзінділерден бала өзін көреді, қоршаған ортасын таниды.

Қорытынды. Түйіндеп айтқанда, балалар әдебиетін, оның ішінде балаларға арналған поэзияны зерттеу кезек күттірмейтін, қайта тездетіп ғылыми тұрғыдан зерттеп-зерделеуді қажет ететін өте өзекті сала болып саналады. Соңғы ширек ғасырда қазақ балалар поэзиясы трансформациялық сипатта дамыды. Қоғамдық-саяси өзгерістер, үлкен тарихи бетбұрыстар өз кезегінде руханиятқа, оның ішінде әдебиет кеңістігіне де әсер етпей қоймады. Балалар 
әдебиетінде жаңа тақырыптар мен түрленген жанрлар пайда болды. Әсіресе, тарихи таным аясындағы ұлттық мәселелер көп қаузалды.

Қазіргі авторлар тарих қойнауында жасырынып жатқан көне кенттер мен есімдері ел есінде болуға тиіс ірі тұлғалар туралы сериялық өлеңдер жазады. Әсіресе, советтік қатаң цензура кезінде есімін атауға тыйым салынған ірі қайраткерлерді жаңа қырынан, тәуелсіз ұлт мүддесі аясында ашып береді. Қазіргі балалар әдебиетінің ірі өкілдерінің бірі Арасанбай Естеннің шығармаларында аталмыш үрдістер айқын аңғарылады. Ақын поэзиясындағы эпикалық поэма жанрынан бастап лирикалық мазақтама жанрына дейінгі аралықта аксиологиялық желі қалыптасқан. Бәрі де баланың бойына ізгілік құйып, жақсылыққа баулуға қызмет етеді. Автордың шығармашылық қызметі педагогика мен поэтика ғылымдарының талап-тілегіне сай жүзеге асады. Шығармаларында автор өз оқырманымен тікелей байланысқа түсіп, оқырманмен диалог құра біледі. Өлең жолдарында геймификациялық элементтерді шебер қолданады. Бұл қазіргі балалар әдебиетінің бір ерекшелігі ретінде қарастыруға негіз бар.

Худайбергенов Н.Д.

Институт литературы и искусства им. М.О. Ауэзова.

Алматы, Казахстан;

E-mail: nqudaibergen@gmail.com

\section{Художественно-аксиологические искания в современной казахской детской поэзии (на основе творчества А. Естена)}

Аннотация. В статье рассматриваются тенденции современной казахской детской литературы и ее особенности. Одним из характерных направлений литературы в период независимости является усиление стремления к возрождению национальных ценностей. Особенно элементы, отражающие уникальность нации, раскрывающие ее историю и традиции, отражающие ее ментальное мироощущение, за последние четверть века нашли свое яркое отражение не только в казахской литературе, но и практически во всей литературе постсоветских стран, освободившихся от ига колониальной политики. Выдающиеся имена и события, вытесненные со сцены истории и навсегда забытые, очень интенсивно воспроизводились в годы после обретения независимости. Этот процесс имеет свое продолжение и по сей день.

В статье дается обзор творческого мира выдающегося представителя современной казахской детской поэзии А. Естена, дается оценка таланта и вкуса поэта в воспевании историко-культурных ценностей. Автор обращает внимание на то, насколько художественные произведения для детей отвечают педагогическим требованиям. Он также останавливается на аксиологической и поэтической деятельности поэзии, пытается раскрыть ее значение в жизни ребенка.

Данная научная статья написана в рамках проекта АР05131632 «Тенденции развития современной казахской детской литературы» (1991-2021 гг.) по грантовому финансированию фундаментальных и прикладных научных исследований по научным проектам Комитета науки МОН РК на 2020-2022 годы.

Ключевые слова: литература, детская литература, поэзия, педагогика, ценности.

Khudaibergenov N.D.

M.O. Auezov Institute of Literature and Art

Almaty, Kazakhstan;

E-mail: nqudaibergen@,gmail.com

Artistic and axiological searches in modern kazakh children's poetry 


\begin{abstract}
The article examines the tendencies of modern Kazakh children's literature and its features. One of the characteristic trends in literature during the period of independence is the strengthening of the desire to revive national values. Especially the elements reflecting the uniqueness of the nation, revealing its history and traditions, reflecting its mental attitude, over the past quarter of a century have been vividly reflected not only in Kazakh literature, but also in almost all the literature of post-Soviet countries that have freed themselves from the yoke of colonial politics. Outstanding names and events, ousted from the stage of history and forgotten forever, were very intensively reproduced in the years after independence. This process continues to this day.

The article provides an overview of the creative world of the outstanding representative of modern Kazakh children's poetry A. Yesten, an assessment of the poet's talent and taste in glorifying historical and cultural values is given. The author draws attention to the extent to which works of art for children meet pedagogical requirements. He also dwells on the axiological and poetic activity of poetry, tries to reveal its significance in the life of a child.

This scientific article was written within the framework of the AR05131632 project «Trends in the development of modern Kazakh children's literature» (1991-2021) for grant financing of fundamental and applied scientific research on scientific projects of the Science Committee of the Ministry of Education and Science of the Republic of Kazakhstan for 2020-2022.
\end{abstract}

Key words: literature, children's literature, poetry, pedagogy, values.

Информация об авторе: Худайбергенов Н.Д., РhD, научный сотрудник Института литературь и искусства им. М.О.Ауэзова, Алматы, Казахстан. E-mail: nqudaibergen@gmail.com, ORCID: 0000-0003-2482-0524, Scopus ID: 57191575739.

\title{
Әдебиеттер:
}

[1] Оксамитный Ю.В., Айдапкелов Н.С. Дети Казахстана: Статистический сборник. Астана, 2017. - С.122.

[2] Мырзалиев Қ. (1982) Алғы сөз // М.Әлімбаев. Аспандағы әпке: өлеңдер, ертегілер, жұмбақтар, жаңылтпаштар. - Алматы: Жалын, 1982. - 135 б.

[3] Ұлт руханияты гуманитарлық ғылымнан не күтеді? Академик Сейіт Қасқабасовпен әңгіме // Егемен Қазақстан. - 2017. - №55 (29036).

[4] Естен А. Тарихи тұлғалар туралы туындылар. 2021 жыл. (Автордың қолжазба мұрағатынан алынды).

[5] Естен А. Көне кенттер күмбірі. балаларға арналған өлеңдер, ертегілер, жұмбақтар мен жаңылтпаштар. - Астана: Фолиант, 2019. - 160 б.

[6] Әлтай А. Д. Қазақ балалар поэзиясы: генеалогия,типология, поэтикалық даму: Филология ғылымдарының докторы ғылыми дәрежесін алу үшін дайындалған диссертация. (10.01.02) / Әлтай, Аманжол Дүйсенбайұлы; Л.Н.Гумилев атынд.Еуразия ұлттық ун-ті. Астана, 2009. - 285 бет.

[7] Жәкім Ә. М.Әлімбаевтың балалар әлемі / Жәкім, Әсел. - Алматы: Арыс, 2008. 228 б.

\section{Литература:}

[1] Оксамитный Ю.В., Айдапкелов Н.С. Дети Казахстана: Статистический сборник. Астана, 2017. С.122.

[2] Мырзалиев К. Предисловие // М. Алимбаев. Сестре небесной: стихи, сказки, загадки, загадки. - Алматы: Жалын, 1982. - С. 135.

[3] Чего духовность нации ожидает от гуманитарных наук? Интервью с академиком Сеитом Каскабасовым // Казахстанская правда. - 2017. - №55 (29036). 
[4] Естен А. Производении об исторических личностях. (Из архива рукописей автора). [5] Естен А. Голос древних городов. Стихи, сказки, загадки и загадки для детей. - Астана: Фолиант, 2019. - С. 160.

[6] Алтай А. Д. Детская казахская поэзия: генеалогия, типология, поэтическое развитие: диссертация на соискание ученой степени доктора филологических наук. (10.01.02) / Алтай, Аманжол Дуйсенбайулы; ЕНУ им. Л.Н.Гумилева. - Астана, 2009. - С. 285.

[7] Жаким А. Детский мир М. Алимбаева / Жаким, Асел. - Алматы: Арыс, 2008. - С.228.

\section{References}

[1] Oksamitny Yu.V., Aydapkelov N.S. (2017). Children of Kazakhstan: Statistical collection. Astana, p.122.

[2] Myrzaliev K. (1982) Foreword // M. Alimbaev. Sister of heaven: poems, fairy tales, riddles, riddles. - Almaty: Zhalyn, p. 135.

[3] What does the spirituality of a nation expect from the humanities? Interview with academician Seit Kaskabasov // Egemen Kazakhstan. - 2017. - No. 55 (29036).

[4] Esten A. (2021). Works about historical figures. (From the author's manuscript archive).

[5] Esten A. (2019) The voice of ancient cities: poems, fairy tales, riddles for children. Foliant Publishing House, p.160.

[6] Altai A.D. (2009). Children's Kazakh poetry: genealogy, typology, poetic development: dissertation for the degree of Doctor of Philology. (10.01.02) / Altai, Amanzhol Duisenbayuly; ENU them. L.N. Gumilyov. - Astana, p. 285.

[7] Zhakim Ә. (2008). Children's world M. Alimbaeva / Zhakim, Asel. - Almaty: Arys, p. 228. 